\title{
Between Rosanvallon \& Rancière: Toward a Theory of Dissentient Democracy
}

\author{
Entre Rosavanllon y Rancière: hacia una teoría de la \\ democracia disidente \\ ROBERT WT MARTIN ${ }^{1}$ \\ Hamilton College, New York, USA
}

\begin{abstract}
Recent efforts to rethink democratic norms are exemplified by two contemporary French thinkers. Pierre Rosanvallon criticizes protest movements and seeks to institutionalize their forces. Jacques Rancière, on the other hand, has famously defined democratic politics as existing only in moments of chaotic re-imagining of the existing order. His approach is revealed as requiring more attention to the reasonable norms of that order than Rancière allows. Such norms constitute a model of dissentient democracy, and can be drawn from the plebian radicals of the American founding era.
\end{abstract}

KEYWORDS

DEMOCRACY, DISSENT, HABERMAS, RANCIÈRE, ROSANVALLON

\section{RESUMEN}

Los intentos más recientes de repensar las normas democráticas están ejemplificados por dos pensadores franceses contemporáneos. Pierre Rosavallon critica los movimientos de protesta y trata de institucionalizar sus fuerzas. Jacques Rancière, por otra parte, ha definido notoriamente la política democrática de forma que se da sólo en momentos en los que se re-imagina caóticamente el orden existente. Su enfoque se revela de forma que reclama más atención hacia las normas razonables de ese

1 The author would like to thank Sam Chambers for his invaluable help, as well as all the participants of the Third Civic Constellation workshop, especially Anat Ascher, Rosario López, and Marta Postigo.

(C) Contrastes. Revista Internacional de Filosofia. Suplemento 20 (2015), pp. 25-37. ISSN: 1136-9922

Departamento de Filosofía, Universiad de Málaga, Facultad de Filosofía y Letras

Campus de Teatinos, E-29071 Málaga (España) 
orden de lo que el propio Rancière admite. Tales normas constituyen un modelo de la democracia disidente, y puede inspirarse en los radicales populares de la era de la fundación americana.

\section{PALABRAS CLAVE \\ DEMOCRACIA, DISENSO, HABERMAS, RANCIÈRE, ROSANVALLON}

From the Arab Spring demonstrations to the Occupy movement to the Maidan protesters in Kiev, the place of political dissent has been on episodic display. But apart from these rare and fleeting moments of popular power, democratic life has been widely seen as in decline, and political theorists have analyzed this decay. In various ways, political philosophers have sought to enliven the norms and forms of modern politics. The French theorist Pierre Rosanvallon, for example, has recently theorized what he (somewhat confusingly) calls «counter-democracy», the emerging practices of public oversight that supplement (and do not actually counter) representative democracy as generally understood. Rosanvallon's approach envisions «a durable democracy of distrust, which complements the episodic democracy of the usual electoralrepresentative system», by adding an emphasis on «vigilance, assessment, and pressure through revelation, obstruction, and judgment». ${ }^{2}$ The «critical sovereignty» of parliamentary and political opposition has declined, he convincingly argues, leaving us today with nothing more than the «negative sovereignty» of «malcontents» who can undermine new proposals but are otherwise impotent, lacking any real mechanism for positive change. ${ }^{3}$

Rosanvallon is correct that though a healthy skepticism can bring about a kind of positive citizen vigilance, it can also give rise to «destructive forms of denigration and negativity». This «negative democracy» is easy to organize, since opponents do not have to agree to anything except that the status quo is unacceptable. And even the minimal demand of transparency can be counterproductive, such as when increased transparency constrains and burdens policymakers to such an extent that they can accomplish nothing, leaving citizens disillusioned and apathetic. ${ }^{4}$ Notwithstanding these risks of negativity, we should not follow Rosanvallon and much of contemporary political philosophy

2 Pierre Rosanvallon, Counter-Democracy: Politics in an Age of Distrust, trans., Arthur Goldhammer. (Cambridge: Cambridge University Press, 2008), 8, 18. For criticisms of the term "counter-democracy» as confusing, see the review symposium in Perspectives on Politics 8 (2010): 887-895, especially 887, 895 .

3 Rosanvallon, Counter-Democracy, 122, 172.

4 Rosanvallon, Counter-Democracy, 24, 183, 258. 
in underestimating the democratic power of these kinds of actions. Recently, Mark Warren has critiqued the field of political theory for the common tendency to ignore «exit-based» strategies of empowerment and communication. ${ }^{5}$ Indeed, political radicals and even common farmers in 1790s America were well aware of the (limited) power these strategies afforded and the messages they sent. ${ }^{6}$

Even more importantly, we should not be too quick to follow Rosanvallon's lead in dismissing unstructured, popular movements and pushing for greater organization and institutionalization. He advocates, for example, consensus conferences and citizen evaluation boards, both of which might well play some role in an invigorated democratic culture. But making improved organization of «counter-democratic powers» the «essential task» of the present moment, as does Rosanvallon, risks channeling political dissent too narrowly and leaving us with the kind of «participatory elitism» (and abandonment of mass democracy) that Simone Chambers justifiably laments. ${ }^{7}$

Since institutionalizing popular power risks undermining it, we might be inclined to embrace the random outbursts of citizen passion. And indeed, some political theorists have sought to address our democratic malaise, but this time rather than over-emphasizing institutionalization, they theorize democracy without the slightest hint of structure. The American political theorist Sheldon Wolin is right to conclude that «the central challenge at this moment is [...] about nurturing a discordant democracy» that acts as a «standing opposition» to anti-democratic norms. He responds, however, by conceptualizing democracy as necessarily «ephemeral» and «fugitive». ${ }^{8}$ This amounts to little more than, as one critic puts it, an «oppositional pessimism». ${ }^{9}$ Similarly, the French thinker Jacques Rancière explicitly defines democracy as the government of «anyone

5 Mark Warren, «Voting with Your Feet: Exit-based Empowerment in Democratic Theory», American Political Science Review 105 (2011): 683-701; see also, Kevin Olson, «Legitimate Speech and Hegemonic Idiom: The Limits of Deliberative Democracy in the Diversity of its Voices», Political Studies 59 (2011): 543; and Stephen K. White and Evan Robert Farr, "'NoSaying' in Habermas», Political Theory 40 (2012): 32-57.

6 For more on this, see Robert W.T. Martin, Government by Dissent: Protest, Resistance, and Radical Democratic Thought in the Early American Republic. (New York: New York University Press, 2013), esp. chap. 2.

7 Rosanvallon, Counter-Democracy, 298-9; more generally, see 294-302; Simone Chambers, «Rhetoric and the Public Sphere: Has Deliberative Democracy Abandoned Mass Democracy?» Political Theory 37 (June 2009): 329-45.

8 Sheldon Wolin, Politics and Vision: Continuity and Innovation in Western Political Thought, exp. ed. (Princeton: Princeton University Press, 2006), 605-6, 604, 602.

9 Edward Wingenbach, Instituting Agonistic Democracy: Post-Foundationalism and Political Liberalism. (Burlington, VT: Ashgate, 2011), 84 
and everyone», seemingly underwriting an anarchic resistance to all narratives and all institutions. ${ }^{10}$ As a result, the political theorist Edward Wingenbach explains, for Rancière, democratic politics «emerges rarely, episodically, and unpredictably». ${ }^{11}$

The fact that Rancière characterizes democratic politics as exceedingly «rare» is not in itself problematic; he may well be right. ${ }^{12}$ And as Joseph Tanke cautions us, many critics emphasize the rarity of politics in Rancière's vision «perhaps with too much satisfaction». ${ }^{13}$ But Rancière's claim about the rarity of democratic politics is not so much an empirical observation as it is theoretical claim about how to understand democracy. And the strict opposition he theorizes between «politics» and «police» lead to some significant conceptual weaknesses in his approach.

For Rancière, democracy is really about «politics», and «politics» can only be found in those extraordinary episodes in which those who are marginalized by the «police» order -that is, the laws and institutions of our communal lifedemand to take their rightful place. This egalitarian instinct is the mechanism of «politics», which by its very nature disrupts «the police». Understandably, then, Rancière's work has almost completely focused on politics (with examples drawn from various protest movements) to the exclusion of attention to the police.

Despite his focus on politics (to which we will return below), Rancière makes «one isolated but striking admission» as Oliver Davis aptly observes: «The police can procure all sorts of good, and one kind of police may be infinitely preferable to another». Davis critiques Rancière here for lacking any explanation of why we should separate the process (politics) from the good end result (preferable police), when the end result might be, for example, a fairer economic distribution. ${ }^{14}$

Davis's point is a good one, but the problem goes much deeper. When first introducing this view of politics in Disagreement, Rancière immediately turns to an economic example, noting how the poor can force their way into having a part in public affairs, thus avoiding economic domination. ${ }^{15}$ By following Rancière

10 Jacques Rancière, Hatred of Democracy, trans., Steve Corcoran. (London: Verso, 2006), 72 .

11 Wingenbach, Agonistic Democracy, 46.

12 Jacques Rancière, Disagreement: Politics and Philosophy, trans., Julie Rose. (Minneapolis: University of Minnesota Press, 1999), 139; see also, 17.

13 Joseph Tanke, Jacques Rancière: An Introduction. (London: Continuum, 2011), 63.

14 Oliver Davis, Jacques Rancière. (London: Polity, 2010), 93. See also Rancière, Disagreement, 31 .

15 Rancière, Disagreement, 11. 
into the economic realm, Davis misses two important aspects of the issue. First, how do we know a particular end result of a protest was «infinitely preferable» or not? To be sure, a fairer distribution might be better simply because it is closer to Rancière's presumption of equality, but even that claim will very likely get much more complicated, thus requiring us to make some distinctions (equal what? Wages? Benefits? Opportunities?); these distinctions, of course, amount to a form of policing. Second, and more importantly, Davis's example ignores -as does Rancière's approach-that some kinds of policing are more democratic than others. Indeed, for Rancière, such a notion of democratic police is flatly contradictory. But here Rancière's polemics are simply misguided. Some kinds of regulations make «politics» as Rancière himself defines it more or less likely, and more or less robust. In particular, regulations and practices that privilege democratic dissent amount to democratic policing. ${ }^{16}$

Rancière's fleeting discussion of «police» concludes: «Whether the police is sweet and kind does not make it any less the opposite of politics». ${ }^{17}$ But again, framing the issue here as whether or not «the police is sweet and kind», directs us away from the pivotal question of whether or not it is conducive to egalitarianism. To be sure, Rancière is on to something here: any regulation is, in the short run, an instance of policing, of one part of society telling another part how to behave. But in the long run, some forms of police, some norms or regulations, make future democratic/egalitarian efforts more likely and more effective. To take perhaps the most obvious example, and one central to Rancière's own stress on education, required schooling is surely an instance of police, including the usual aspects of inequality and hierarchy (as parents tell teenagers how to behave, and even presume the teenagers have no say in the matter). Yet if that required education leaves the student with a basic literacy and numeracy (even resulting exclusively from the inspiration but not explanation of an «ignorant schoolmaster» ${ }^{18}$ ), then the student is much better prepared to engage in robust performances of equality, the central element in Rancière's image of politics.

The fact that Rancière's strict opposition between politics and police is overdrawn is not simply an analytical problem. As the example above suggests, it fails to appreciate how some forms of police are not simply «sweet» or «preferable» but are actually conducive to a more legitimate, because more egalitarian, politics. The problem here, however, goes much deeper, to the very

16 For an insightful analysis of Rancière's «police», see Samuel A. Chambers, The Lessons of Rancière. (New York: Oxford University Press, 2013), chap. 2.

17 Rancière, Disagreement, 31

18 See Jacques Rancière, The Ignorant Schoolmaster: Five Lessons in Intellectual Emancipation. (Stanford: Stanford University Press, 1991). 
core of Rancière's definition of politics.Rancière draws his view of politics repeatedly from two classical sources, the oldest of which is Plato's discussion of the various principles of ruling. Each of these principles is unremarkable (e.g., the wise should rule), except the final principle listed: rule by lot. This, for Rancière, is the scandalous introduction of (democratic) politics, the rule of anyone and everyone, the taking part in governance by «the part that has no part». This is his celebrated «miscount», when those who have no legitimate claim to be counted, insist on being counted. ${ }^{19}$

There is a problematic aspect to this source and, though it is fairly obvious, to my knowledge, Rancière never addresses it. Though rule by lot in ancient Athens did have the monumental element of supplementing or even rejecting other principles of ruling by replacing, for instance, the justification of wealth with the justification of mere citizenship, it also embodied aspects of policing by its necessary reliance on regulating citizenship: rule by lot empowered «anyone and everyone» to rule, so long as he was not a woman, a teen-ager, a slave, or a non-Athenian.

As I said, Rancière does not address this problem directly, but he does get around it by suggesting, in his recurring appeal to his second classical source, that the Athenian notion of politics was not simply a matter of including the otherwise excluded poor. Aristotle, in Book I of the Politics, draws his famous distinction between the human («political») animal who has the faculty of speech (and can thus can consider justice) and the non-human animals who merely have voice (and can thus only express pain and pleasure). ${ }^{20}$ This approach, then, avoids the regulative policing implicit in Plato's reference to rule by lot (for citizens).

Rancière, consistent with this broader approach, goes further, not only drawing from Aristotle here, but also critiquing the element of police implicit in this strict distinction between those who are understood by society as being capable of logos (reasoned speech) and those who are not. In Aristotle's own vision, and indeed throughout human history, many groups have been excluded from a role in the public sphere precisely on the (usually implicit) grounds that they do not really «speak», and thus have to part in public affairs. In Disagreement, Rancière points to «the falseness of evidence of any decisive opposition between human beings endowed with the logos and animals restricted to sole use of the organ of the voice». Joseph Tanke observes that elsewhere, Rancière asserts that «there

19 See, e.g., Rancière, Disagreement, 1-6; see also, Jacques Rancière, Dissensus: On Politics and Aesthetics, ed.s and trans.s Steven Corcoran. (London: Continuum, 2010), 30-31, 51, and Jacques Rancière, «Ten Theses on Politics», Theory and Event 5 (2001): para. 9-12.

20 Aristotle, Politics, I, 1253a 9-17; see also, Rancière, Disagreement, 1, and Rancière, Dissensus, 37-38. 
is no meaningful distinction between perceiving and possessing reason». «Political activity», for Rancière, «demonstrates the sheer contingency of the order, the equality of any speaking being with any other speaking being». Democracy, then, is precisely «the regime -the way of life- in which the voice [...] usurps the privileges of the logos, which allows the just to be recognized $[\ldots] \gg .{ }^{21}$

Rancière's efforts here to avoid the sharp distinction that Aristotle drew is problematic in a couple of ways. First, as Oliver Davis observes, much of Rancière's «own work tends to preserve the clear-cut opposition between human speech and animal noises». ${ }^{22}$ For example, central to Rancière's theory is his oft-repeated claim that democracy involves «the equality of any speaking being with any other speaking being». ${ }^{23}$ The centrality of this claim indicates that once again the problem goes deeper than is often recognized. For if Rancière wants to avoid being, like Aristotle, illegitimately restrictive regarding who gets to claim to speak (as he often but not always does), then this raises the question of whether there is any limitation on who (or what?) can legitimately claim the right to speak. Can women and slaves? Great. Literate teen-agers? Ok, fine. Semi-literate nine-years-olds? My dog?

In fact, Rancière routinely elides these kinds of questions. Early in Disagreement, he tells us that democracy was scandalous because it meant that simply being born in Athens («once enslavement for debt was abolished») meant any artisan could «speak». Thus, the demos takes up the «equality that belongs to all the citizens». ${ }^{24} \mathrm{Here}$, then, Rancière notes the «scandalous» force of democracy by way of conceding that the exclusion of slaves undermined this force. The exclusion of women, teenage boys, and non-citizens, however, remains unexamined, just as it was in his discussion of Plato's Laws.

Rancière chooses to draw on several historical examples throughout his works, but even these more developed discussions silently dodge this question of whether there is any legitimate, necessary policing of the borders of politics. His examples of the Secession of the Plebs and striking workers, especially the tailors' strike in 1833, would seem to invite him to discuss the gendered limits to these moments of politics. Instead, we see the return to chiefly economic issues highlighted in the discussion of policing. ${ }^{25}$

21 Rancière, Disagreement, 21; Tanke, Rancière, 57; Rancière, Disagreement, 30, 22.

22 Davis, Rancière, 92.

23 Rancière, Disagreement, 30 (emphasis added); see also, 42, 49.

24 Rancière, Disagreement, 7, 8.

25 See, e.g., Rancière, Disagreement, 23-7; and Jacques Rancière, On the Shores of Politics, trans., Liz Heron. (London: Verso, 1995), 45-52; and Tanke, Rancière, 60. For Rancière's limited engagement with feminism, see Davis, Rancière, 44-8. 
Rancière would most likely respond to the limitations of these examples by casting them as precisely that, limitations of these particular examples, not his broader theory, which is meant to explore the anti-foundationalist contingency of any police order. But that leaves us committed to the equality between all «speaking» beings, where the claim to «speak», to employ logos and reason, must be left unpoliced. But, again, what then of teenagers? Infants? Animals?

As Joanne Faulkner notes, Rancière does not pursue these (marginal?) cases. ${ }^{26}$ In The Ignorant Schoolmaster, of course, he focuses on university students and also cites the example of human children learning language not by instruction so much as simply listening and figuring it out for themselves. ${ }^{27}$ It is this radical pedagogy that lies at the origins of Rancière's theory of politics. For him, «democracy means a commitment to the equality of intelligence», the political theorist Sam Chambers explains. «This capacity for anyone to read [a book, even one in a language they do not know], without having someone else tell him what it means -this is the power of equality, and this is all there is to equality»-. ${ }^{28}$ But why must one be able to read? Why is literacy the core of this view of egalitarianism that is the core of democracy, which is to say, of politics?

To be sure, the expectation that the political actors in our communities must be able to read, or at least speak, is perfectly reasonable. But that does require that we accept the role of some idea of reason and allow some policing of our politics, two moves Rancière rejects. This is not only a matter of showing that Rancière's anti-foundationalism is untenable, but further and more importantly, that we need to make some account of which capabilities make politics as Rancière defines it, as a practice of dissensus, both more likely and more effective. The core problem, then, is not that Rancière, as a matter of consistency, needs to be willing to accept a dog's bark as a legitimate performance of equality, but rather that we need a theory of democratic politics that privileges dissent, and therefore not only allows us but requires us to police the moral boundaries between a protest sign and a firebomb, between a suffragette demanding the vote and a petulant teenager disputing a curfew. ${ }^{29}$

Elsewhere, I have developed a concept of what I call dissentient democracy, asserting that genuine popular politics requires a recognition of the essential

26 Joanne Faulkner, «Negotiating Vulnerability Through 'Animal' and 'Child': Agamben and Rancière at the Limit of Being Human», Angelaki 16 (2011): 80-83.

27 Rancière, The Ignorant Schoolmaster, 5.

28 Chambers, The Lessons of Rancière, 13, 30.

29 On Rancière's failure to analyze the place of violence in the dissenting politics he champions, see Davis, Rancière, 98-99. 
place of challenges to the ever-present domination of the status quo (i.e., the dominant existing norms and practices, as well as the authorities -philosophical as well as institutional-that support them) ${ }^{30}$ Like Rancière, I turn to a historical protest movement, but unlike him I explore how we might make our police more or less democratic. The American radicals of the 1790s were especially well placed to analyze these issues because they were forced to examine and defend the place of dissent in the face of arguably the first modern democracy.

For American Federalists -that is, supporters of the new, 1787 Constitution- dissent simply had no place in popular politics. Alexander Hamilton and George Washington, for example, thought that the very idea of a «loyal opposition» was incoherent. Against this theoretical and cultural norm, the radicals who challenged the Washington administration not only sought to legitimate the very principle of dissent, but they conceptualized ways in which the structures of society, Rancière's police, might be reformulated so as to encourage, even privilege, dissent.

Some of the challenges to a dissentient democracy confronted by these opposition thinkers were institutional and fairly obvious. Simply getting access to the public sphere, via the newspapers of the day, was a hurdle, as many newspapers baldly refused to print views critical of existing authorities and norms. But even when addressing this straightforward, mechanical problem, these early theorists perceived that most newspapers were beholden to the business interests that provided much of the economic support for the newspaper business. Additionally, these theorists came to recognize that elite figures and ideas were less reliant on this medium that they controlled than were the plebian protesters, because the governmental and economic elite -then as now-is wellconnected through private channels that are simply unavailable to non-elite challengers of the status quo. ${ }^{31}$

These early radical thinkers were also perceptive about more subtle features of existing norms that can undermine dissent and thus need revision in a dissentient democracy. Elite control of the public discourse was sometimes, in fact, anything but subtle. Even the mildest critics of the proposed new constitution in 1787 were characterized as traitors and mere «scribblers» who had no right to be questioning the work of unassailable figures - «great names»- such as Washington and Franklin. ${ }^{32}$ Only slightly more subtle was the elite capture

30 See Martin, Government by Dissent, esp. 1-5.

31 See Martin, Government by Dissent, chap. 3.

32 See, e.g., Centinel II, Freeman's Journal, 24 October 1787, in The Documentary History of the Ratification of the Constitution, ed. Merrill Jensen et al. (Madison: State Historical Society of Wisconsin, 1976-), 13: 458, 459. 
of the label, «Federalist», leaving their opponents to be caricatured as «AntiFederalist», the term we still use today. ${ }^{33}$

A more nuanced avenue to controlling the debate and undermining dissent was Federalist dominance of the legal community and the educated elite. Throughout much of the 1790s, Federalists drew heavily on their position as well-educated citizens, many with legal training, to assert their authority in questions of public policy and constitutional law. The «Democratic Societies», radical political clubs popular in the middle of the decade, frequently criticized these elite claims to legitimate authority and sought ways to combat these Federalist advantages. ${ }^{34}$ These efforts included repeated calls for free, public schools, intended to educate the poor beside the well-born. ${ }^{35}$ There were even efforts to get around the elitedominated legal system by establishing independent mediation boards to handle disputes equitably. ${ }^{36}$ Perhaps most sophisticated were critiques that highlighted the way that influential Federalists sought to interpret the law, and especially the new Constitution, in terms that forced dissenters onto the defensive. As the plebian radical William Manning aptly observed in 1798, the brief and ambiguous Constitution was intentionally «made like a Fiddle, with but few Strings, but so that the ruling Majority could play any tune upon it they pleased». ${ }^{37}$

Another way that status quo powers use their outsized influence to undermine oppositional discourse is simply to point public attention toward a more sensational -and normally less fundamental- issue. This «politics of distraction» was becoming evident to the most incisive of these early radical theorists. «Philadelphiensis», a prominent but still unknown critic of the proposed constitution, insisted that readers «consider the thing more attentively», focusing on the substance of objections to elite views and ignoring attacks on the person voicing those objections. Otherwise, «all investigation of the subject would cease; the whole attention would be drawn off to another object», the personality of the critic. ${ }^{38}$

33 See, e.g., Aristocrotis, Government of Nature Delineated, in The Complete Anti-Federalist. (hereafter, $C A-F$ ), 7 vols., ed. Herbert Storing (Chicago: University of Chicago Press, 1981), 3: 209.

34 See Martin, Government by Dissent, chap. 4.

35 See, e.g., Philip S. Foner, The Democratic-Republican Societies, 1790-1800: A Documentary Sourcebook of Constitutions, Declarations, Addresses, Resolutions, and Toasts. (Westport, CT: Greenwood Press, 1976), 108, 322, 323.

36 See Foner, Democratic-Republican Societies, 125.

37 Manning, The Key of Liberty [1798], in The Key of Liberty: The Life and Democratic Writings of William Manning, ed. Merrill and Wilentz. (Cambridge: Harvard University Press, 1993), 222.

38 Philadelphiensis VIII, Independent Gazetteer ( $C A-F$ 3: 125). 
Perhaps the most robust insight of these early radicals was their analysis of a democratic society's need for anonymous outlets into the public sphere. Long before the advent of modern whistleblower protection laws, eighteenth-century Anglo-American printers maintained a tradition of non-attributed writing that allowed marginalized writers -Rancière's «part that has no part»-into political debate. When this norm came under attack at the end of the century, radicals explored how this would discourage the dissent that must be, they maintained, privileged ${ }^{39}$ If popular politics is to be meaningful, what we now call a «chilling effect» must not be allowed to silence would-be dissenters; rather, these chilling effects must be avoided by regulative norms that encourage challenges to the status quo.

To be sure, modern efforts to avoid chilling any dissenting speech necessarily involve us in complicated questions of who qualifies as a «whistleblower» and to whom, in this era of blogging, journalist shield laws apply. As Rancière reminds us, these are matters of police, structuring norms that can be problematic for dissent. For example, today's «citizen journalists» might well claim they are the «part that has no part», the people that these kinds of laws «miscount». My point, however, is that we can and must make morally informed choices among various kinds of these policing norms. As these 1790s radicals understood, it is not simply a matter of which norms are sweeter, kinder, or preferable, but which ones are conducive to genuine democracy.

I have briefly touched on some early American radical thought precisely to highlight the centrality of dissent to democracy, but I am not claiming that dissent alone is sufficient to achieve democracy, only that it is necessary, more necessary than is generally understood. The radical democrats of the 1790 s knew that political action and dissentient questioning could not be incessant; they all had to work for a living too. Yet they refused to let popular politics be as rare or ephemeral as Rancière suggests; they refused to let the daily toil of farm or worktable get in the way of political contestation.

Indeed, some of Rancière's own earlier, historical examples are at least suggestive about the way past political struggles can leave their marks upon the police order, as when declarations of equality won by one struggle can provide the foundation for a later struggle. ${ }^{40}$ But what has been most influential among political philosophers is precisely his abstract vision of politics as «specifically

39 See Martin, Government by Dissent, chap. 3.

40 E.g., Rancière, On the Shores of Politics, 48-9; see also, Jacques Rancière, «The Thinking of Dissensus: Politics and Aesthetics», in Reading Rancière, ed. Paul Bowman and Richard Stamp. (London: Continuum, 2011), 5. 
opposed to the police». ${ }^{41}$ And it is this bald distinction that is simply untenable, both for Rancière's thought and for democratic theory more generally. We need to recognize and theorize the nature of democratic police. As Chambers observes, Rancière is «content to leave [the concept of police] under theorized». ${ }^{42}$ He should not be content, and we cannot afford to be. With Chambers, we need to avoid common anarchist readings of -and elements in-Rancière's work, and instead theorize «a democratic politics more $[\ldots]$ attendant to the possibility of transforming the police order». ${ }^{43}$ Otherwise, «Rancière's theory may encourage us», as Peter Hallward cautions, «to do little more than 'play at' politics or equality». ${ }^{44}$ This risks leaving us to marvel at glorious moments of political frisson, only to return to the interminable domination and inequality of a police order that is neither preferable nor sweet.

As an alternative, an invigorated and dissentient democracy might best be thought of neither as Rosanvallon's slate of new oppositional organizations (though they often help) nor as Rancière's fleeting moments of police-defying contention (though they too will have their place), but rather as an ongoing «revolution both permanent and quotidian», in Jürgen Habermas's apt phrase. Our democratic regimes have been host to innumerable illegitimate events and policies, going all the way back to founding moments when now-revered «framers» simply asserted public authority. But our ongoing efforts at constitutionremaking contributes to a continual «self-correcting learning process» whereby we redeem and extend that revolution. ${ }^{45}$ Or at least we can, and sometimes do. Habermas sees the «New Deal» of the Roosevelt era as just such a moment, while Rancière famously draws on the May'68 movement in Paris. Each of these involved revolutionary re-imaginings of the existing order and centered on dissent, both institutionalized and more anarchic. Yet these historic moments are neither permanent nor in any sense quotidian.

41 Jacques Rancière, «Ten Theses on Politics», Theory \& Event 5 (2001): thesis 7.

42 Chambers, The Lessons of Rancière, 67.

43 Chambers, The Lessons of Rancière, 87; and cf., e.g., Todd May, «Rancière and Anarchism» in Jacques Rancière and the Contemporary Scene: The Philosophy of Radical Equality, ed. Jean-Philippe Deranty and Alison Ross. (London: Continuum, 2012).

44 Peter Hallward, «Staging Equality: Rancière’s Theatrocracy and the Limits of Anarchic Equality», in Jacques Rancière: History, Politics, Aesthetics, eds., Gabriel Rockhill and Philip Watts. (Durham, N.C.: Duke University Press, 2009), 157.

45 Jürgen Habermas, Between Facts and Norms: Contributions to a Discourse Theory of Law and Democracy, trans., William Rehg. (Cambridge: MIT Press, 1996), 471; Jürgen Habermas, «Constitutional Democracy: A Paradoxical Union of Contradictory Principles?», Political Theory 29 (2001): 774. 
Though it privileges dissent, a dissentient approach cannot guarantee that we will avoid apathy and instead actively and continually engage in productive self-examination, critique and reformation; but underestimating the centrality of dissent, as most political theorists do, or dismissing the regulative norms that privilege dissent, as does Rancière, virtually guarantees that we will fail to make good the revolutionary democratic project. 
